\title{
V. S. Naipaul: an Unwelcome Guest of India; with Reference to an Area of Darkness
}

Mr. Chimata Suresh

Assistant Professor, Department of English

Bapatla Engineering College

Andhra Pradesh, India

Dr. G. Chenna Reddy

Associate Professor, Department of English

Acharya Nagarjuna University

Andhra Pradesh, India

Abstract

This research paper is an attempt to analyze the reason for many Indian nationalists finds Naipaul's An Area of Darkness as an unfitting description of India. The book is banned in India as soon as it was published for showing India in a poor light. In this research paper, the researcher advocates the opinions of many critics, who feel that Naipaul had been very harsh and blunt in describing India. The researcher quotes various reviews and articles to support his views in this paper. The researcher quotes the lines from the book to support his argument. Although V. S. Naipaul is an Indian by origin, he is mostly influenced by the western way of living and unable to take the fact that his expectations about India have not been met. Appreciating the narrative style of Naipaul, the researcher concludes that An Area of Darkness is biased in many aspects. Travelers are the reason for the ills in Indian Society and any other traveler, who tries to exploit any such ills are not welcomed to India.

Keywords: V. Naipaul, An Area of Darkness, Negative Perspective, Banned book in India. 
Introduction

Naipaul's two books about India, entitled "An Area of Darkness" (1964) and "India: A Wounded Civilization" (1977), are based on his personal experiences of visiting India in 1962 and 1975 respectively. Though these books are considered as travelogues, they are to be seen as the Non-Fiction Novels. "The Area of Darkness", which is subtitled as an "Experience of India" is based on Naipaul's visit to his parent's homeland. It appears as if he had great expectations of India, which failed to have been met. It appears that he spews all the disappointment in the book. There is every country in the world has its own vices and virtues. India has its own problems. India was the biggest economy in the world for so many years until the British invaded the country. During the British rule, the GDP of India had been 0.01. So, India's development had stalled for two hundred years; Poverty and other problems shot up due to it. Selling India's poverty to sell their books is not new to this country. Some writers have highlighted 'untouchability', some wrote on the 'problems of the women in India'. V.S. Naipaul is no different. His narrative style is so impressive in such a way that any Indian who reads the book feels inferior to the western world. That could be why the book had been banned in India as soon as it was published.

Naipaul's Negative perspective of India:

Naipaul gets carried away by what he sees instead of the reason for the picture and judges India by the visual aspect. All he observes in the country is full of smudge, hungry and ill people and beggars everywhere. Indian poverty is what he finds so painful. He describes people pooping in public and dirty beggars craving alms create. Almost every Indian he sees is diminutive and dark. If the person is physically unattractive, they are either moral demeanours or intellectually inferior.

"In Madras, the bus station near the High Court is one of the more popular latrines. The traveller arrives; to pass the time, he raises his dhoti, defecates in the gutter. The 
bus arrives; he boards it; the woman sweeper cleans up after him. Still, in Madras, observe thus bespectacled patriarch walking past the university on the Marina". (Naipaul2010:70)

We can observe in the above lines that there is a lot of generalization and usage of simple present tense. Irrespective of the country or a place that we visit and when we come back from there, any individual talks about the great things they have seen at that place, even if we catch some ugly sight as V. S. Naipaul sees, we ignore it, and we do not talk about it later. When our mind is conditioned to see something, we come across to see only those things, which we call a law of attraction. There are many travelogues by the westerners, who have visited India. They didn't glorify India blindly. They have seen beauty in simple living, whereas Naipaul sees it in the opposing perspective. Amrit, in his review for a website, writes about the book as,

"Everywhere he goes, and people are scheming, but scheming like stupid children who aren't even smart enough to scheme properly. If you can manipulate properly, it means you have a degree of intelligence, which Naipaul does not want to attribute to the people he comes across. They always want to swindle money out of him. Even the people, who seem to grow close to him, are eventually trying to get some money." (Amrit 2018)

Amrit and Murtaza are the present generations of Indian youngsters. They are not writers or famous critics; social media allows everyone to express their Indian's after the fourth generation Internet revolution in India are being active of social media platforms, with their improved English Language Proficiency. They make their presence felt by expressing what they think about anything. Murtaza in his review:

"This is the first book by Naipaul that has helped me understand why people disliked him so much. It's an insufferably arrogant account of a traveller through India who 
does not speak the language and has no meaningful understanding of its history. $\mathrm{He}$ goes purely by gut and what he produces is an astoundingly negative portrait. He depicts India as a grotesque dystopia, doomed by its fatalism to eternal misery. We can see in retrospect that this judgment was a bit hasty" (Murtza 2019)

Pico Iyer who is also an Indian Origin Foreigner and traveller. He visited India just like V.S. Naipaul; the researcher wants to quote the following from his travelogue article from New York Times to bring home the point that poverty in India can also be seen positively:

"Yet walk just 10 minutes out of town, and you come to shady rustic lanes where people with old faces are working in the fields or walking to the temple as if they've never heard of Paris (or Paris Hilton). One day I found musicians sitting on the ground among the poplars, playing at intervals while a team of elegant men in black robes took on a team of elegant men in white in a traditional archery competition. The day's scores were chalked up on a blackboard, and each side danced before and during the competition" (Iyer 2014)

In fact, Naipaul's perception of India is skewed, coloured, and shaped by too much Western assumptions, which explains why he feels repulsion rather than desire for his ancestral homeland. Furthermore, as a tourist in India, Naipaul was in the midst of a transitional phase and so unable to project accurate insights into India or get at the true reality of India. Nissim Ezekiel objections to Naipaul's views and observations expressed against India in his article "Naipaul's India and Mine".

Naipaul, in the book, is seen as an impatient and hypersensitive traveller, Even Mahatma Gandhi is no exception to his criticism, and it has received a lot of backlashes from so many critics. His skepticism towards modern Indian swamis and Gandhi have raised so many doubts about his attitude and invited criticism. The prominent critics who have taken him to the task are Nissim Ezeikeil and C.D. Narasimhaiah. L.K Sharma opines that V.S Naipaul 
was lucky to have got away because there was not much criticism from India back then, and also Indian's are very open-minded to accept him to come to India repeatedly:

"Fortunately, An Area of Darkness was published when Indians had not yet discovered "the extreme form of literary criticism" that has in recent years silenced more than one writer. So, the book was just discussed and not burnt by those offended by the book. Nor did the book prevent Naipaul from visiting his ancestral land again and again. He was welcomed warmly and assisted by volunteers during his travels and interviews for his subsequent books." (Sharma 2018)

The greatness of the Indian democracy system and the broad-minded nature of Indians have let him visit again and again and write his negative views of India. We see that many countries do not issue Visas to such people who negatively project their country. Present India and India's youth are not as broad-minded or their ancestors; Indian youth are all social media. Any criticism against any system in India is taken very seriously by them, and the population and the numbers of users also have an impact. Those celebrities or any other foreigner is either made to tack back their comments, or they are forced to explain it further to pacify the Indians on social media.

Conclusion:

We might conclude that Naipaul's portrayal of India in "An Area of Darkness" is heavily influenced by his Western assumptions. His first meeting with the Indian Society also affects his views on India. There is beauty everywhere, particularly in a country like India, often known as the subcontinent. There are so many things to be thankful for. What we write is a reflection of ourselves. V.S. Naipaul's expectations of India were not met. Had V.S. Naipaul been alive and come to India and write anything similar to the trilogy, he would not have the same hospitality on the literary platforms. He would have invited a mammoth criticism from the youth of India. So, now V.S. Naipaul is not welcome to India. 


\section{References}

Primary Source:

Naipaul, Vidiadhar Surajprasad. "An Area Of Darkness". Picador: London 2010.

Secondary Sources:

Hallan, Amrith. "My Review of an Area Of Darkness By V.S. Naipaul". Medium, 2018, https://amrithallan.medium.com/my-review-of-an-area-of-darkness-by-v-s-naipaul3c497c29b0fb.

Murtaza "An Area Of Darkness". Goodreads.Com, 2019, https://www.goodreads.com/book/show/5854.An_Area_of_Darkness. Accessed 10 Feb 2021.

Iyer, P., 2014. Heaven's Gate (Published 2014). [online] Nytimes.com. Available at: https://www.nytimes.com/2008/05/18/t-magazine/travel/heavens-gate.html

Sharma, L., 2018. Naipaul: an abandoned child looks and relooks at the motherland. [online] open Democracy. Available at:

https://www.opendemocracy.net/en/openindia/naipaul-abandoned-child-looks-andrelooks-at-motherland/ [Accessed 18 February 2021]. 